\title{
The echinoid genus Echinogalerus in the Maastrichtian type area
}

\author{
R. Van der Ham \& M. Van Birgelen ${ }^{2}$ \\ 1 Piet Heinstraat 6, NL-2628 RK DELFT, the Netherlands; \\ e-mail: Ham@nhn.leidenuniv.nl \\ 2 Widdershovenstraat 9, NL-6367 HVVOERENDAAL, the Netherlands
}

Manuscript received: July 2000; accepted: November 2001

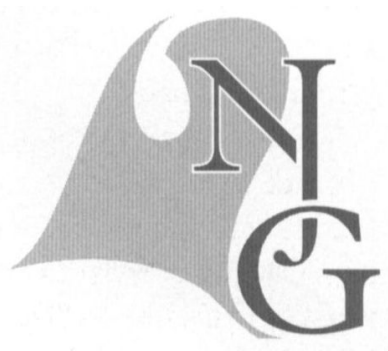

\begin{abstract}
The Late Cretaceous echinoid genus Echinogalerus König, 1825 is remarkably diverse in the Maastrichtian type area (SE Netherlands and adjacent parts of NE Belgium and western Germany). So far, five species have been recognised, namely $E$. belgicus (Lambert, 1898), E. minutus (Smiser, 1935), E. muelleri (Schlüter, 1902), E. pusillus Lambert, 1911 and E. vetschauensis (Schlüter, 1902), which occur from the base of the Lower Maastrichtian (E. belgicus, E. pusillus, E. muelleri) up to the K/T boundary (E. minutus). Echinogalerus muelleri, which has the longest stratigraphical range, is the most diverse, while $E$. pusillus is the smallest echinoid in the area, reaching maximum lengths of $4.5 \mathrm{~mm}$. Comparisons with other species of Echinogalerus described in the literature have now led to the recognition of three tentative infrageneric alliances. It is argued that the ordinal position of Echinogalerus (Holectypoida or Cassiduloida) cannot be evaluated as long as many species are still insufficiently known and two genera, from the Maastrichtian of northern Germany and Denmark, intermediate between the two orders, remain undescribed.
\end{abstract}

Keyzords: Maastrichtian, echinoids, taxonomy

\section{Introduction}

The genus Echinogalerus comprises small irregular echinoids known from Cenomanian to Maastrichtian strata in NW Europe. Lambert \& Thiéry (1921) listed twenty-one species, and since then, three more have been described (Smiser, 1935; Kongiel, 1950). A number of regional revisions were published during the last decades (Ernst, 1973; Kutscher, 1979; Van der Ham et al., 1987; Smith et al., 1988, 1999; Smith \& Wright, 1999; Neumann et al., 2002), but the genus has never been comprehensively monographed. The aim of the present paper is to revise, as a prelude to a more inclusive study, the species from the Maastrichtian type area.

\section{History}

Müller (1846) was the first to record a species of Echinogalerus from the Maastrichtian type area (Vetschau, see Fig. 1). That author, and later also Binkhorst van den Binkhorst (1859) and Bosquet (1860, 1868, 1879) referred to it as Caratomus gehrdensis, a species described by Roemer (1841) from the Santonian of Hannover (northern Germany). However, Schlüter (1902) recognised it as a new species, $C$. muelleri, and in the same paper erected $C$. vetschauensis, also from Vetschau. Lambert (1911) introduced as new Echinogalerus belgicus and E. pusillus, both from Slenaken. The former had earlier been described by Lambert (1898) from southern Belgium as var. belgica of Caratomus peltiformis 


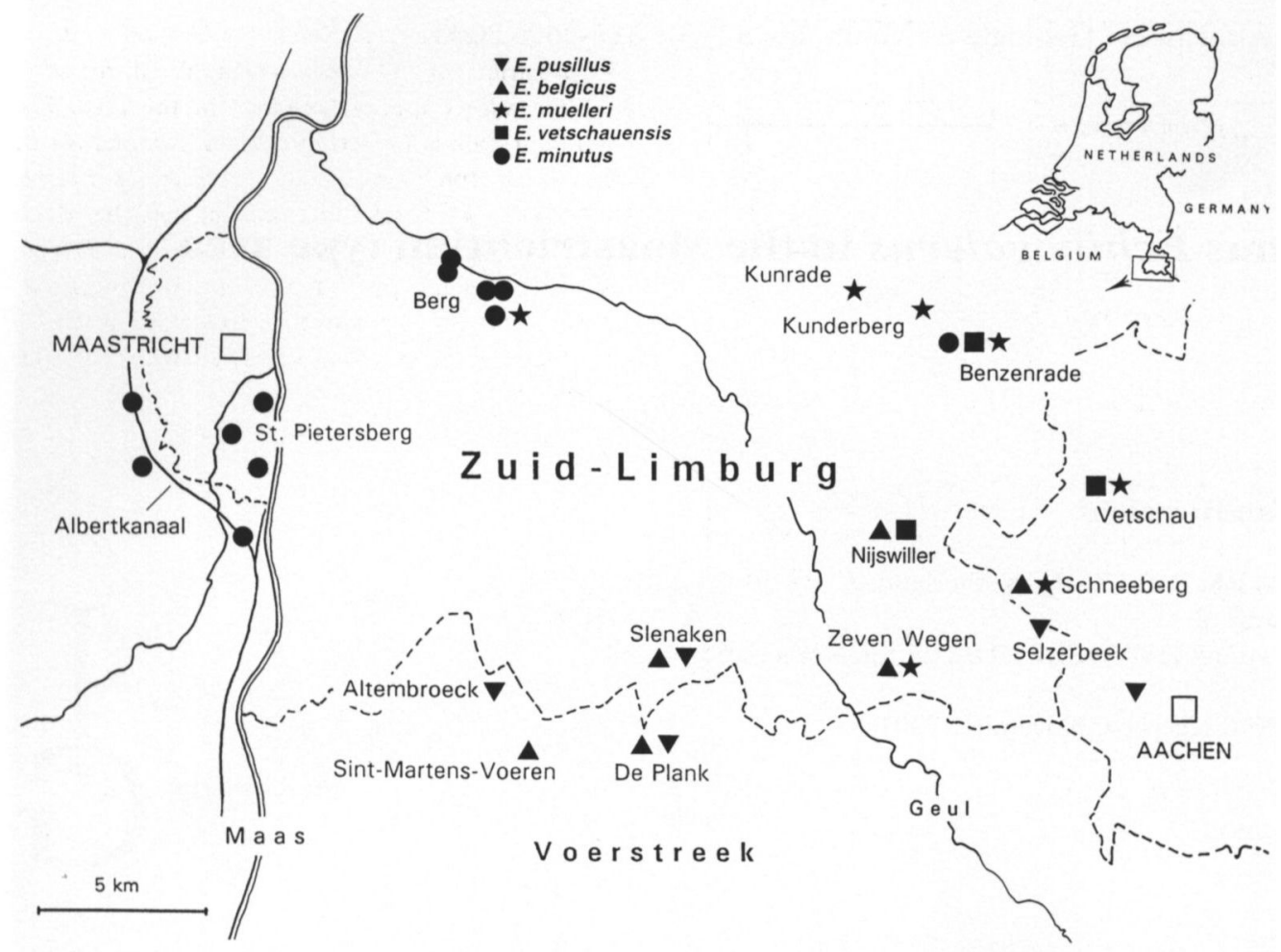

Fig. 1. Map of the Maastrichtian type area, showing localities from which species of Echinogalerus have been collected.

Wahlenberg, 1821, a species from the Lower Campanian of southern Sweden. Although Lambert (1898) pointed out that the genus name Echinogalerus König, 1825 predated Caratomus Desor, 1842, he did not use that genus name until 1911. Smiser (1935) described two new species from the St Pietersberg near Maastricht, viz. Faujasia? transversa and Pseudopyrina minuta. Both were transferred to Echinogalerus by Meijer (1956). Although Meijer (1965) covered the entire Maastrichtian type area, he listed only two species of Echinogalerus, namely E. belgicus and E. transversus. Van der Ham et al. (1987) briefly discussed five species (E. belgicus, E. minutus, E. muelleri, E. transversus and $E$. vetschauensis), while the then single known specimen of $E$. pusillus was considered a possible juvenile of $E$. belgicus. Van der Ham \& Van Birgelen (1992) recorded numerous specimens of $E$. belgicus and a few of E. muelleri from the Schneeberg near Vaals. Abundant new material has subsequently been collected of the poorly known $E$. pusillus and $E$. transversus. This triggered a preliminary revision of Echinogalerus in the Maastrichtian type area. Van Birgelen \& Van der Ham (1999) dealt with material from the Gulpen Formation, listing three species, viz. E. belgicus, E. pusillus and Echinogalerus sp. 1, while Van der Ham \& Van Birgelen (2000) listed material from the Maastricht Formation (E. minutus $[=E$. transversus], E. muelleri, E. vetschauensis and Echinogalerus sp. 2). A new species from the Gulpen Formation was referred to as Echinogalerus sp. 3 by Van Birgelen \& Van der Ham (2000). In the present revi- sion, Echinogalerus sp. 1 and Echinogalerus sp. 2 are considered to be variants of E. muelleri, and Echinogalerus sp. 3 a slightly deviating form of $E$. vetschauensis, so that at present the following five Echinogalerus species are distinguished in the Maastrichtian type area: E. belgicus, E. minutus, E. muelleri, E. pusillus and $E$. vetschauensis. Two of these are restricted to the Gulpen Formation, one to the Maastricht Formation, while the other two species occur in both the Gulpen and Maastricht formations (Fig. 2).

\section{Systematic descriptions}

Repositories - The following abbreviations are used in the text to denote the repositories of specimens referred to and/or illustrated:

IRScNB Institut royal des Sciences naturelles de Belgiques, Brussels;

NHMM Natuurhistorisch Museum Maastricht, Maastricht (BL - L. Blezer Colln, JJ J.W.M. Jagt Colln, GK - W.M. Felder Colln (Gulpen Formation), K - M.M.M. Kuypers Colln, MK - W.M. Felder Colln (Maastricht Formation), MM - M. Meijer Colln, RH - R.W.J.M. van der Ham Colln).

Measurements are given as: minimum (mean) maximum. 


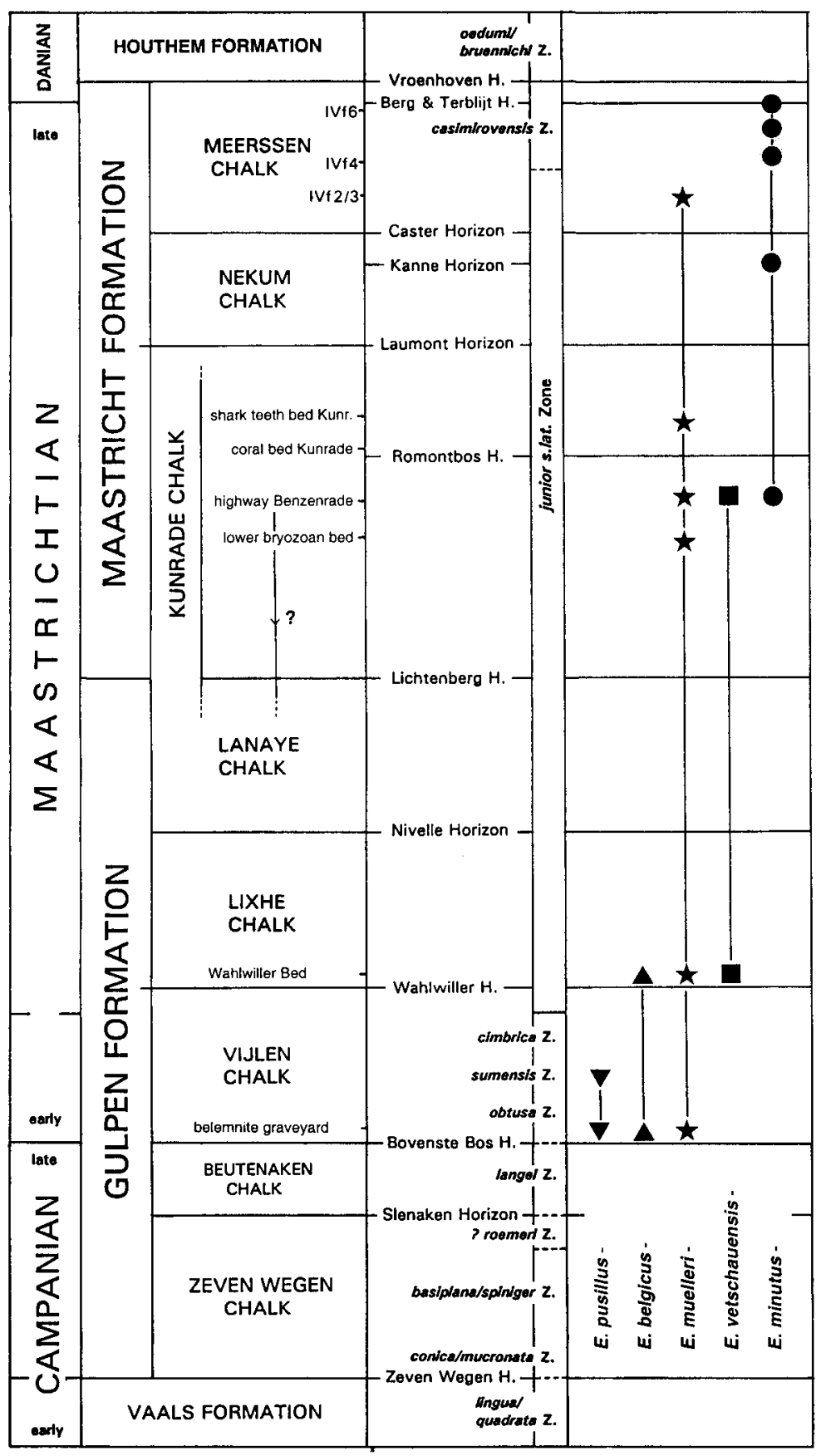

\section{1 - Species from the Gulpen Formation}

Echinogalerus belgicus (Lambert, 1898)

Figs 3, 4, 5e-h, 12a

1857 Caratomus sulcato-radiatus Desor - d'Orbigny, p. 371 , pl. 942, figs 7-11.

1875 Caratomus avellana Agassiz - Cotteau, p. 650.

1896 Caratomus avellana Cotteau - de Grossouvre, p. 305.

^1898 Caratomus peltiformis Wahlenberg var. belgica Lambert, p. 158, pl. 4, figs 11-14.

1911 Echinogalerus belgicus Lambert, pp. 45, 64, pl. 1 , figs $28-35$.
Fig. 2. Stratigraphy of Cretaceous-Danian strata in the Maastrichtian type area, showing the distribution of Echinogalerus species collected in the area. The Kunrade Chalk is the easterly facies of strata to the west which (probably) include the upper Lanaye Chalk up to the basal Emael Chalk; note that these westerly strata have not yielded any species of Echinogalerus. The relative position of the levels 'Benzenrade highway outcrop' and 'lower bryozoan bed' is uncertain; these levels may actually correlate with the upper Lanaye Chalk.
1921 Echinogalerus belgicus Lambert - Lambert \& Thiéry, p. 332.

1935 Echinogalerus belgicus Lambert - Smiser, p. 43.

1965 Echinogalerus belgicus Lambert - Meijer, p. 23.

1987 Echinogalerus belgicus Lambert - Van der Ham et al., p. 28 , pl. 9, fig. 1 .

1992 Echinogalerus belgicus (Lambert) - Van der Ham \& Van Birgelen, p. 149, pl. 3, figs 5, 6.

1999 Echinogalerus belgicus (Lambert) - Van Birgelen \& Van der Ham, p. 215, figs 4e-h, 5a-d.

2000 Echinogalerus belgicus (Lambert) - Smith \& Jeffery, p. 160.

2000 Echinogalerus belgicus (Lambert) - Jagt, p. 254. 

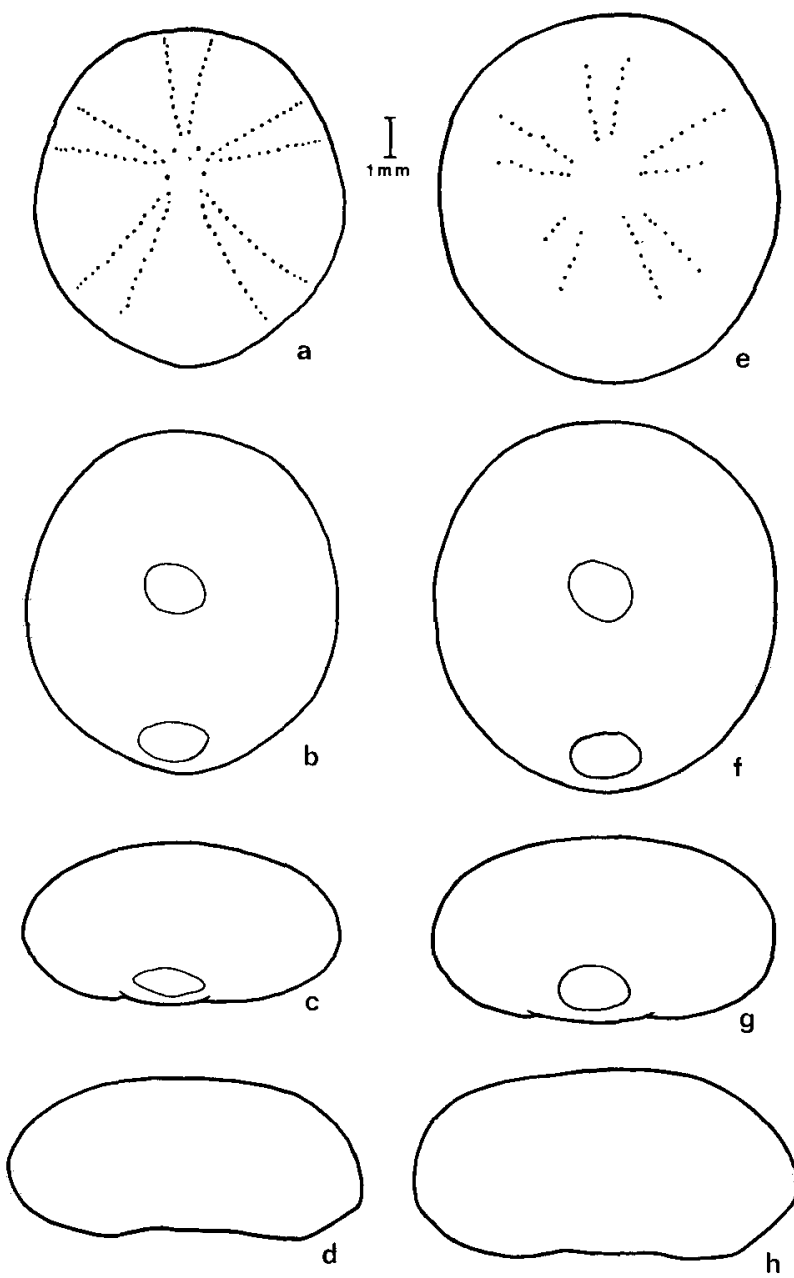

E. belgicus

Fig. 3. Camera-lucida illustrations of E. belgicus (a-d: length 8.5 mm, NHMM MM 829, Vijlen Chalk (belemnite graveyard), Slenaken; e-h: length $9.3 \mathrm{~mm}$, NHMM RH 466, Lixhe Chalk, Wahlwiller Bed, Schneeberg). a, e: upper surface; b, f: lower surface; $c$, g: posterior; $d, h$ : left side.

\section{Types}

Holotype is IRScNB 9135, paratype is IRScNB 9136, from the 'craie phosphatée et poudingue de la Malogne, Ciply’, Belgium.

\section{Material studied}

Van Birgelen Colln, nos $477^{\star}, 1378$; NHMM GK 584, GK 665, GK 1401, GK 1429, GK 1671, GK 1704, NHMM MM 808, MM 829, MM 868, NHMM RH $466^{\star}, 607^{\star}, 750^{\star} ; 68$ specimens in all ${ }^{\star}{ }^{\star}=$ measured specimens from the Schneeberg).

\section{Occurrence}

Lower and Upper Maastrichtian (GULPEN FORMATION), Vijlen Chalk (basal belemnite graveyard) of
Sint-Martens-Voeren, De Plank, Slenaken, Zeven Wegen; Lixhe Chalk (Wahlwiller Bed) of Nijswiller, Schneeberg (Figs 1, 2). Also known from southern Belgium (Mons Basin), Craie phosphatée de Ciply (Lower Maastrichtian) and Poudingue de la Malogne (basal Danian, including reworked elements from underlying Maastrichtian strata). Records for northern Spain (e.g. Lambert, 1927; Gallemí, 1977) have subsequently been referred to $E$. muelleri (Smith et al., 1999).

\section{Description}

Test length 4.1 (8.4) $12.3 \mathrm{~mm}$, width 0.85 (0.89) $0.93 \%$ of length, height $0.42(0.50) 0.61 \%$ of length. Outline usually elliptical, widest at or occasionally posterior of midlength. Profile depressed. Lower surface relatively flat. Ambulacra nonpetaloid; pores single aborally. Peristome obliquely elliptical. Periproct inframarginal, slightly larger than peristome, transversely elliptical to obtusely triangular. Tubercles distinct, slightly more pronounced at anterior, inconspicuous above periproct.

\section{Remarks}

Echinogalerus belgicus may be recognised by its elliptical, depressed shape and the single-pored aboral ambulacral plates. The type material has not been studied. Therefore, conspecificity of the material from southern Belgium and that from the Maastrichtian type area relies entirely on Lambert (1911). In both areas, species occur (although more rarely) which might be confused with $E$. belgicus, but which can be distinguished by their double aboral pores, viz. E. $r u$ toti (Lambert, 1898) in southern Belgium and $E$. muelleri (Schlüter, 1902) in the Maastrichtian type area. If single aboral ambulacral pores in the Belgian specimens of E. belgicus could be demonstrated (a fact not explicitly described, nor illustrated by Lambert), this would confirm conspecificity with populations from the Maastrichtian type area.

Echinogalerus pusillus Lambert, 1911

Figs 4, 5a-d, $12 \mathrm{~b}$

*1911 Echinogalerus pusillus Lambert, p. 65, pl. 1, figs 10-14.

1921 Echinogalerus pusillus Lambert - Lambert \& Thiéry, p. 332.

1935 Echinogalerus pusillus Lambert - Smiser, p. 43.

1956 Echinogalerus pusillus Lambert - Meijer, p. 42.

1987 Echinogalerus pusillus Lambert - Van der Ham et al., p. 28. 


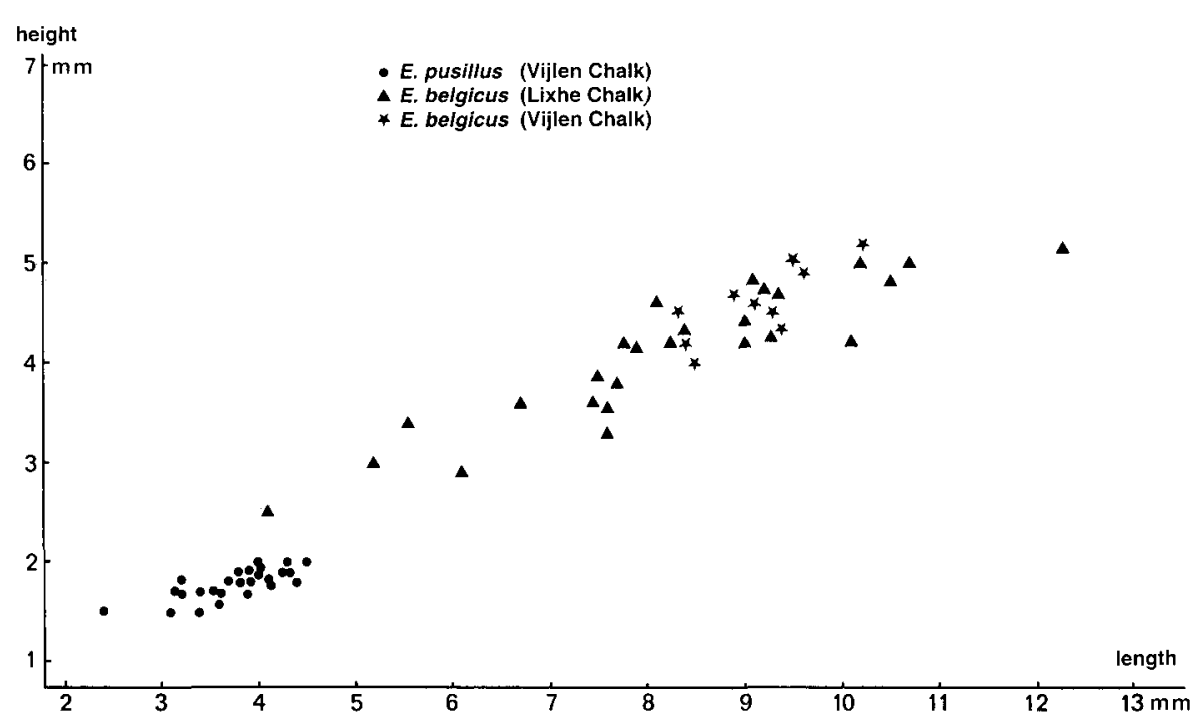

Fig. 4. Graph showing height/length values of a number of well-preserved specimens of E. belgicus (Lixhe Chalk, Wahlwiller Bed), Schneeberg $(n=26)$; Vijlen Chalk (belemnite graveyard), Sienaken and Zeven Wegen $(\mathrm{n}=10)$ and $E . p u$ sillus (Vijlen Chalk, sumensis Zone), Selzerbeek $(n=26)$.

1995 Echinogalerus belgicus (Lambert) - Jagt et al., p. 12.

1999 Echinogalerus pusillus Lambert - Van Birgelen \& Van der Ham, p. 215, fig. 4a-d.

2000 ?Echinogalerus belgicus (Lambert) - Smith \& Jeffery, p. 160.

2000 Echinogalerus pusillus Lambert - Jagt, p. 254.

Types

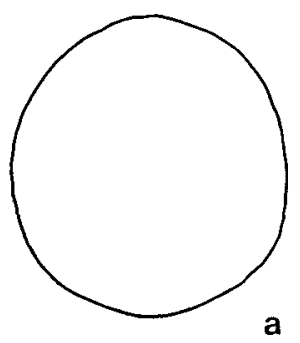

Holotype is IRScNB 9137, from the 'Craie marneuse de Slenaken', the Netherlands.

\section{Material studied}

NHMM RH 658*; Van Birgelen Colln, nos 522, 1205, 1239*; Halter Colln, unnumbered; Walschot Colln, unnumbered $\left({ }^{\star}=\right.$ measured specimens, $\mathrm{n}=$ $26)$; in all some 100 specimens.

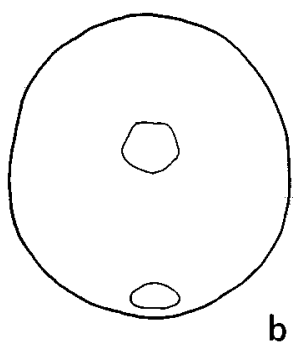

\section{Occurrence}

Lower Maastrichtian (Gulpen Formation), Vijlen Chalk (basal belemnite graveyard and sumensis Zone) of Altembroeck, De Plank, Slenaken (type material), Selzerbeek, Aachen-Steppenbergallee (Fig. 2). Not known outside the Maastrichtian type area.

\section{Description}
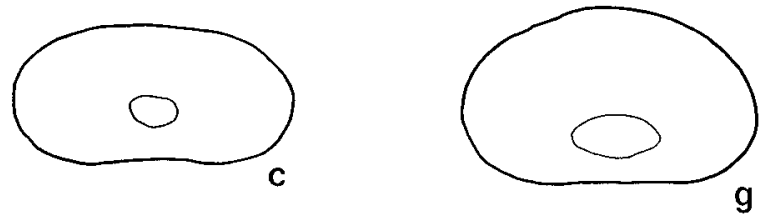

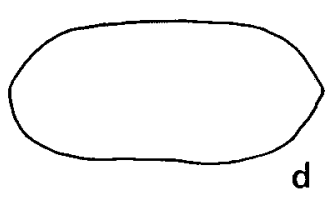

E. pusillus
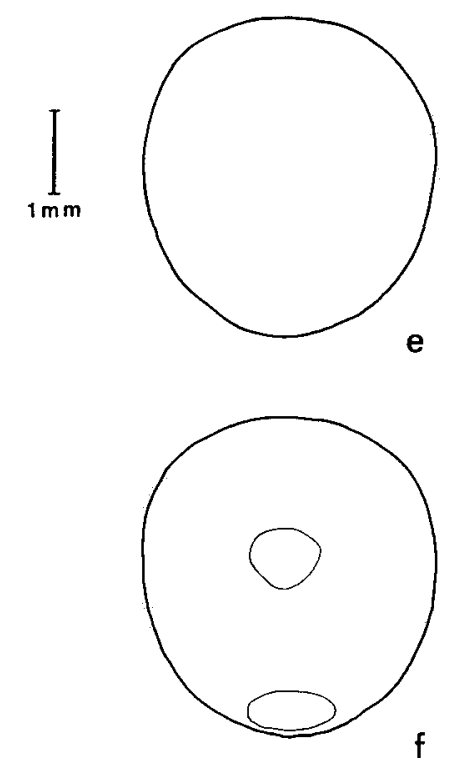

b

$f$

Test diminutive, length 2.4 (3.8) $4.5 \mathrm{~mm}$, width 0.87 (0.91) $0.97 \%$ of length, height $0.41(0.48) 0.62 \%$ of length. Outline elliptical, widest at or slightly posterior of midlength. Profile depressed. Lower surface relatively flat. Ambulacra nonpetaloid; pores single aborally. Peristome obtusely pentagonal. Periproct infra-

Fig. 5. Camera-lucida illustrations of $E$. pusillus (a-d: length 3.9 $\mathrm{mm}$, NHMM RH 658, Vijlen Chalk (sumensis Zone), Selzerbeek), and a more or less equal-sized specimen of $E$. belgicus (e-h: length $4.1 \mathrm{~mm}$, NHMM RH 466, Lixhe Chalk (Wahlwiller Bed), Schneeberg. a, e: upper surface; $b$, f: lower surface; c, g: posterior; $d$, h: left side. 
marginal, relatively small, transversely elliptical to indistinctly triangular. Tubercles relatively few and large, slightly more pronounced at anterior side, inconspicuous above periproct.

\section{Remarks}

Echinogalerus pusillus may be recognised by its small size, depressed shape and obtusely pentagonal peristome. The single aboral ambulacral pores are mostly very difficult to observe.

Previously but a single specimen was known, and Van der Ham et al. (1987) considered E. pusillus to be a possible juvenile of E. belgicus. However, on the basis of abundant material collected subsequently, Van Birgelen \& Van der Ham (1999) argued that E. pusillus is a 'good' species, differing clearly from small specimens of E. belgicus (Figs 4, 5). Three specimens of $E$. pusillus $(3.9,3.9,4.3 \mathrm{~mm}$ in length) show four gonopores.

The present species is the smallest echinoid known to date from the Maastrichtian type area, and may be found in numbers only by intensive sieving.

As far known, E. pusillus is endemic to the Maastrichtian type area, and does not resemble any of the other Echinogalerus species.

\section{2 - Species from the Gulpen and Maastricht for- mations}

Echinogalerus muelleri (Schlüter, 1902)

Figs 6-8, 12c

1846 Caratomus gehrdensis Roemer - Müller, p. 8.

1859 Caratomus gehrdensis Roemer - Binkhorst van den Binkhorst, pp. 65, 120.

1860 Caratomus gehrdensis Roemer - Bosquet, p. 406.

1868 Caratomus gehrdensis Roemer - Bosquet, p. 379.

1879 Caratomus gehrdensis Roemer - Bosquet, p. 227.

^1902 Caratomus Mülleri Schlüter, 1902, p. 316, pl. 11, figs 14-17; pl. 12, fig. 30 .

1921 Echinogalerus muelleri Schlüter - Lambert \& Thiéry, p. 332.

1980 Echinigalerus sp. [sic] - Felder, p. 47, pl. 7, fig. 3.

1987 Echinogalerus muelleri (Smiser) - Van der Ham et al., p. 28, pl. 9, fig. 3.

1992 Echinogalerus muelleri (Schlüter) - Van der Ham \& Van Birgelen, p. 149, pl. 3, fig. 7.

1999 Echinogalerus sp. - Van Birgelen \& Van der Ham, p. 217, fig. 5e-h.
1999 Echinogalerus muelleri (Schlüter) - Smith et al., p. 100, pl. 2, figs 17-20.

2000 Echinogalerus muelleri (Schlüter) - Van der Ham \& Van Birgelen, p. 37, fig. 5a-d.

2000 Echinogalerus sp. 2 - Van der Ham \& Van Birgelen, p. 39, fig. 6a-1.

2000 Echinogalerus muelleri (Schlüter) - Smith \& Jeffery, p. 158, text-fig. 66I-L.

2000 Echinogalerus muelleri (Schlüter) - Jagt, p. 254, pl. 16, figs 6, 7 .

2000 Echinogalerus sp. 1 - Jagt, p. 255.

2000 Echinogalerus sp. 2 - Jagt, p. 256.

Types

Schlüter (1902) based his description on a specimen in the Joseph Müller Colln (Aachen), from the 'obere Kreide von Vetschau bei Aachen', Germany; accord-
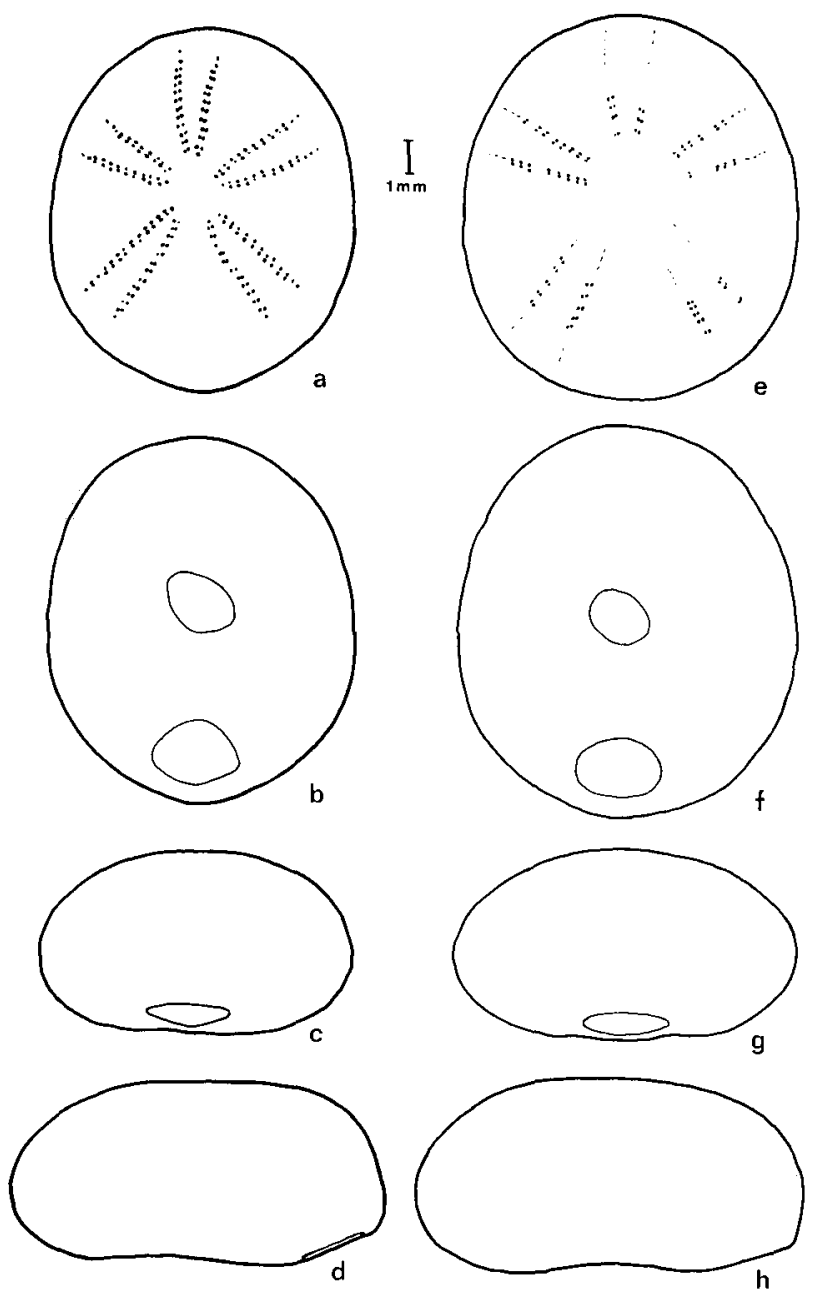

E. muelleri

Fig. 6. Camera-lucida illustrations of E. muelleri (a-d: length 11.6 mm, NHMM RH 108), Kunrade Chalk, Benzenrade highway outcrop; e-h: length $12.2 \mathrm{~mm}$, NHMM GK 1440, Vijlen Chalk (belemnite graveyard), Zeven Wegen). a, e: upper surface; b, f: lower surface; c, g: posterior; $\mathrm{d}$, h: left side. 
ing to W.M. Felder (pers. comm., November 1983), this specimen is lost.

\section{Material studied}

Van Birgelen Colln, nos 25, 377, 413, 414, 477, 506, 655, 1301; NHMM BL 0822, NHMM GK 1440, NHMM MM 817 (Orp-le-Petit), NHMM RH 108, RH 253, RH 258, RH 540, RH 566; Nillesen Colln, unnumbered; Vlieks Colln, unnumbered ${ }^{\star}$; Zuidema Colln, no. E265; in all 199 specimens ${ }^{\star}{ }^{\star}=$ measured specimens from Benzenrade, $n=49$ ).

\section{Occurrence}

Lower and Upper Maastrichtian (GULPEN ForMATION), Vijlen Chalk (basal belemnite graveyard) of
Zeven Wegen; Lixhe Chalk (Wahlwiller Bed) of Schneeberg; (MAASTRICHT FORMATION), Kunrade Chalk of Kunrade (shark teeth bed), Kunderberg (lower bryozoan bed), Benzenrade (highway outcrop), Vetschau (type material), and Meerssen Chalk (IVf2/3) of Blom quarry, Berg (Figs 1, 2). Also known from the base of the Maastrichtian at Orp-le-Petit (Belgium), and the Maastrichtian of northern Spain (Smith et al., 1999).

\section{Description}

Test length 7.6 (11.2) $18.4 \mathrm{~mm}$, width 0.75 (0.85) $0.91 \%$ of length, height $0.39(0.51) 0.60 \%$ of length. Specimens from the Blom quarry are considerably smaller (see Remarks below). Outline elliptical to ovate, widest at or slightly posterior of midlength.
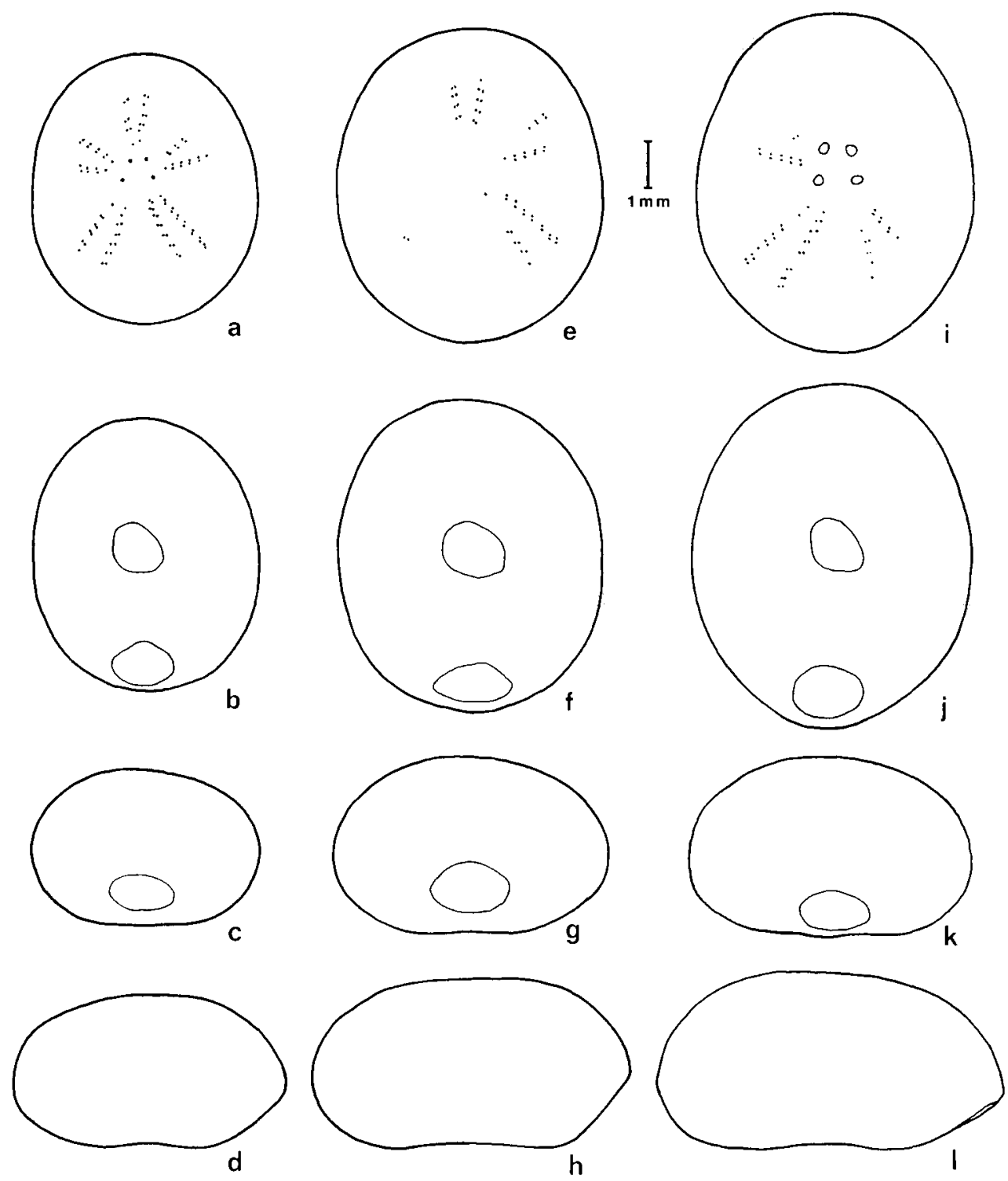

Fig. 7. Camera-lucida illustrations of three small specimens of E. muelleri (length $6.0,6.9,7.4 \mathrm{~mm}$, Van Birgelen Colln, no. 377, Meerssen Chalk, IVf $2 / 3$, Blom quarry, Berg). a, e, i: upper surface; $b, f, j:$ lower surface; $c, g, k$ : posterior; $\mathrm{d}, \mathrm{h}, \mathrm{l}$ : left side. 
Profile usually (see Remarks) depressed. Lower surface slightly pulvinate. Ambulacra subpetaloid; pores double aborally. Peristome irregularly triangular to obliquely elliptical. Periproct inframarginal, clearly larger than peristome, transversely elliptical to obtusely triangular. Tubercles distinct, usually more pronounced at anterior side, inconspicuous above periproct.

\section{Remarks}

Echinogalerus muelleri may be recognised by its triangular to obliquely elliptical peristome and relatively large periproct. Specimen no. 1301 in the Van Birgelen Colln. deviates slightly from the other specimens from the Kunrade Chalk in being relatively high (height/length: 9.8/15.5) and having a more homogeneous tuberculation. The latter characteristic is also found in specimens from the Gulpen Formation.

Stratigraphically, the present species is the most widely distributed one. Previously, this material was subdivided into three separate taxa, as follows:

\section{Gulpen Formation: Echinogalerus sp. 1 \\ Kunrade Chalk: $\quad$ E. muelleri \\ Meerssen Chalk: $\quad$ Echinogalerus sp. 2}

Material from the Meerssen Chalk (Blom quarry) differs from other specimens in being almost consistently smaller and slightly less depressed (length 3.9 (6.2) $8.7 \mathrm{~mm}$, width/length $0.80(0.83) 0.87$, height $/$ length $0.53(0.57) 0.63 ; \mathrm{n}=24)$. However, constant qualitative differences could not be found. For that reason, the three are here lumped into a single species. There is an additional reason to assign these small specimens to $E$. muelleri: of several other co-occurring echinoid species, e.g. Procassidulus lapiscancri (Leske, 1778) and Pleurosalenia maestrichtensis (Schlüter, 1892), relatively small specimens occur, which might indicate that environmental factors played a role. In northern Spain, Smith et al. (1999) found horizons with small individuals of E. muelleri only.

Echinogalerus muelleri is probably closely related to or even conspecific with E. rutoti (Lambert, 1898) from the Poudingue de la Malogne in southern Belgium. This species also has a relatively large periproct, and resembles the small specimens of E. mueller $i$ from the Meerssen Chalk. One individual of E. muelleri from Orp-le-Petit (NHMM MM 817) was initially identified by its collector Max Meijer as E. rutoti. Remarkably, E. rutoti was not mentioned by Lambert (1911) in his description of co-occurring E. belgicus.
Echinogalerus vetschauensis (Schlüter, 1902)

Figs 9, 10, 12d

^1902 Caratomus vetschauensis Schlüter, p. 318, pl. 11 , figs 10-13; pl. 12, fig. 29.

1921 Echinogalerus vetschauensis Schlüter - Lambert \& Thiéry, p. 332.

1987 Echinogalerus vetschauensis (Schlüter) - Van der Ham et al., p. 28, pl. 9, fig. 5.

1999 Echinogalerus? vetschauensis (Schlüter) - Smith et al., p. 100, pl. 2, figs 13-16.

2000 Echinogalerus vetschauensis (Schlüter) - Van der Ham \& Van Birgelen, p. 38, fig. 5e-h.

2000 Echinogalerus? vetschauensis (Schlüter) - Smith \& Jeffery, p. 160.

2000 Echinogalerus sp. 3 - Van Birgelen \& Van der Ham, p. 266, fig. 2a-h.

2000 Echinogalerus vetschauensis (Schlüter) - Jagt, p. 255.

Types

Schlüter (1902) based his description on three specimens from the 'unteren Maastricht-Schichten (Kalken von Vetschau) bei Aachen', in the collections of the Museum der Technischen Hochschule (Aachen). According to W.M. Felder (pers. comm., November 1983), the material is probably lost.

\section{Material studied}

NHMM RH 758; Van Birgelen Colln, nos $716^{\star}$, 1378; Van Loo Colln, unnumbered ${ }^{\star}$; Vlieks Colln, unnumbered ${ }^{\star}$; in all 17 specimens $(*=$ measured specimens from Benzenrade, $\mathrm{n}=7$ ).

\section{Occurrence}

Upper Maastrichtian (Gulpen Formation), Lixhe Chalk (Wahlwiller Bed) of Nijswiller; (Maastricht Formation), Kunrade Chalk of Benzenrade (highway outcrop), Vetschau (type material) (Figs 1, 2). Also known from the Maastrichtian of northern Spain (Smith et al., 1999).

\section{Description}

Test length $13.2(16.2) 18.2 \mathrm{~mm}$, width $0.89(0.94)$ $0.96 \%$ of length, height $0.46(0.52) 0.59 \%$ of length. Measured specimens from Nijswiller $(n=8)$ are smaller and more depressed (length 10.9 (12.6) 15.4 $\mathrm{mm}$, height/length $0.41(0.43) 0.45)$. Outline broadly elliptical to almost circular, widest at midlength. Profile (much) depressed. Lower surface pulvinate. Am- 
bulacra nonpetaloid; pores seemingly single aborally: pores of one pair close set and sunken in a small pit. Peristome slightly obliquely elliptical to almost circular. Periproct inframarginal, relatively small, transversely elliptical to obtusely triangular. Tubercles small, not more pronounced, or hardly so, at anterior side, inconspicuous above periproct.

\section{Remarks}

Echinogalerus vetschauensis may be recognised by its almost circular shape and peristome, and the relatively small periproct and tubercles.

In well-preserved specimens, the aboral ambulacral pores seem to be single (Fig. 9a-d), but in abraded tests (Fig. 9e-h) the pores can be seen lying closely together, being actually double. This fact was not yet fully appreciated by Van Birgelen \& Van der Ham (2000), who described the well-preserved 'singlepored' specimens as a separate, though closely related species (Echinogalerus sp. 3).

Echinogalerus vetschauensis is probably closely related to E. tenuiporus (Schlüter, 1902) from the 'Mucronaten-Kreide' of Grimme (type material) and the Lower Maastrichtian of Rügen (Kutscher, 1979), both in northern Germany.

\section{3 - Species from the Maastricht Formation}

Echinogalerus minutus (Smiser, 1935)

Figs $8,11,12 \mathrm{e}$

^1935 Pseudopyrina minuta Smiser, p. 42, pl. 4, fig. 3a-e.

1935 Faujasia? transversus Smiser, p. 65, pl. 7, fig. 1a-e.

1956 Echinogalerus (Rostrogalerus) transversus (Smiser) - Meijer, p. 38, text-figs 1-3; pl. 1, figs 1 5.

1956 Echinogalerus minutus (Smiser) - Meijer, p. 42.

1965 Echinogalerus transversus (Smiser) - Meijer, p. 23.

1987 Echinogalerus minutus (Smiser) - Van der Ham et al., p. 28, pl. 9, fig. 2 .

1987 Echinogalerus transversus (Schlüter) - Van der Ham et al., p. 28, pl. 9, fig. 4.

2000 Echinogalerus minutus (Smiser) - Van der Ham \& Van Birgelen, p. 35, fig. 4a-1.

2000 Echinogalerus minutus (Smiser) - Smith \& Jeffery, p. 161.

2000 Echinogalerus transversus (Smiser) - Jagt, p. 255, pl. 16, fig. 5 .
Types

Holotype of Pseudopyrina minuta, from the '(upper) Maestrichtian of St. Pierre', the Netherlands, is IRScNB 9134); holotype of Faujasia? transversus, from the 'Maestrichtian of St. Pierre' is IRScNB 9185.

\section{Material studied}

Van Birgelen Colln, nos 95, 107, 108*, 416, 784*, 1299; NHMM JJ 9521*, NHMM K 750*, NHMM MK 736, MK 1205, NHMM MM 567, MM 847, MM 866, MM 867, NHMM RH 628*; Vlieks Colln, unnumbered; a total of 240 specimens ${ }^{\star}{ }^{\star}=$ measured specimens from Blom quarry, $n=76$ ).

\section{Occurrence}

Upper Maastrichtian (MAASTRICHT FORMATION), Kunrade Chalk of Benzenrade (highway outcrop); Nekum Chalk (slightly above Kanne Horizon) of Vechmaal; Nekum or Meerssen Chalk of Leeraarsgroeve near Berg, St Pietersberg (type material), Albertkanaal-St Pietersberg; Meerssen Chalk (IVf4, IVf6, Berg en Terblijt Horizon) of quarries Barakkenberg, Blom, Curfs, Geulhemmergroeve (all near Berg), St Pietersberg West, ENCI-Maastricht BV, and Albertkanaal near Vroenhoven ( $N$ and $S$ of bridge) (Figs 1,2). Not known from outside the Maastichtian type area.

\section{Description}

Test length $3.4(6.3) 8.8 \mathrm{~mm}$, width $0.80(0.85) 0.9 \%$ of length, height $0.42(0.51) 0.63 \%$ of length. Outline ovate, widest posterior of midlength. Profile depressed. Lower surface slightly concave. Ambulacra subpetaloid; pores double aborally. Peristome lengthwise elliptical. Periproct marginal to inframarginal (slightly supramarginal to marginal in small specimens), slightly larger than peristome, transversely elliptical. Tubercles distinct, more pronounced at anterior side, inconspicuous above periproct.

\section{Remarks}

Echinogalerus minutus may be recognised by its ovate, depressed shape and lengthwise elliptical peristome.

Until recently, there was a lot of confusion over $E$. minutus, with the juvenile and adult forms having been described as separate species ( $P$ minuta and $F$.? transversus, respectively) by Smiser (1935). Meijer (1956) placed both species in Echinogalerus. Van der Ham et al. (1987) referred to the adult form as $E$. 


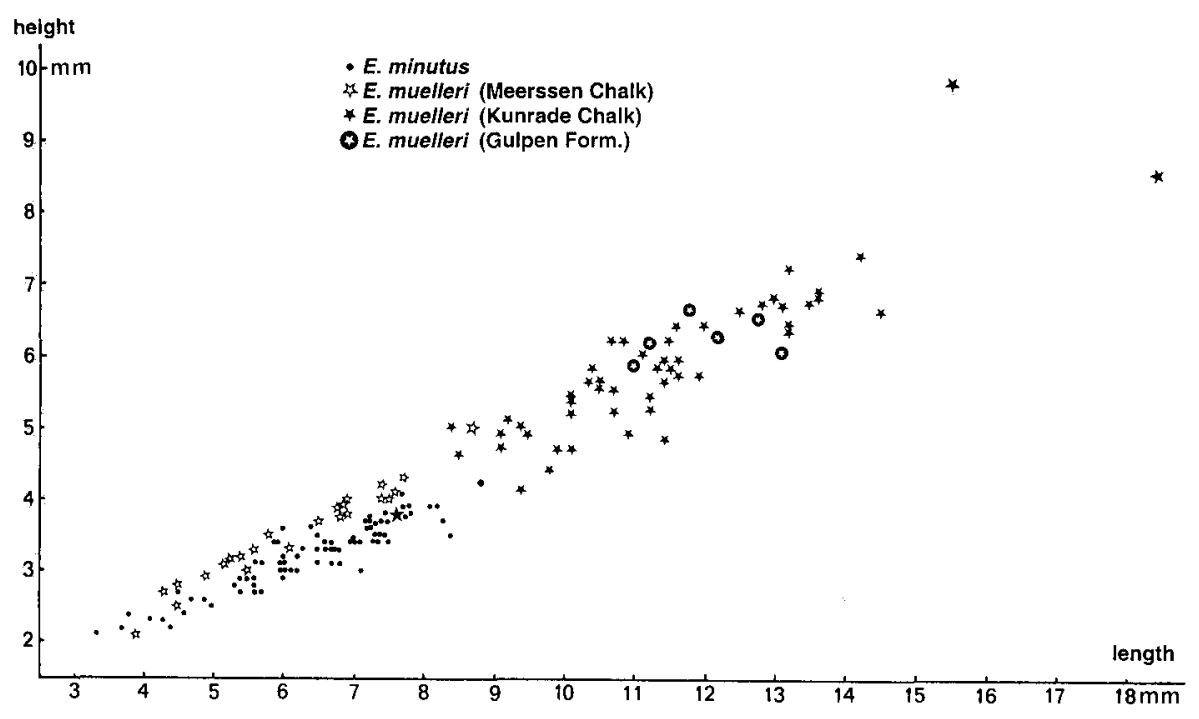

Fig. 8. Graph showing height/ length values of a number of well-preserved specimens of $E$. minutus (Meerssen Chalk, IVf4 and IVf6, Blom quarry, Berg, $\mathrm{n}$ $=76$ ), and $E$. muelleri (base Maastrichtian, Orp-le-Petit, $\mathrm{n}=$ 1; Vijlen Chalk (belemnite graveyard), Zeven Wegen, $\mathrm{n}=$ 1; Lixhe Chalk (Wahlwiller Bed), Schneeberg, $n=4$; Kunrade Chalk, highway Benzenrade, $\mathrm{n}=52$; Meerssen Chalk, IVf2/3, Blom quarry, Berg, $\mathrm{n}=$ 24).

minutus, while their $E$. transversus appeared to represent small specimens of $E$. muelleri.

Fig. 11 illustrates three specimens of increasing size, demonstrating the shift of the periproct from (supra)marginal (young 'minutus form') to inframarginal (adult 'transversus form'), which is common in growing irregular echinoids.

As far we know, E. minutus is endemic to the Maastrichtian type area, and bears little resemblance to any of the other Echinogalerus species described (see below, under Infrageneric alliances).

\section{Ordinal position of Echinogalerus}

Whether Echinogalerus should be assigned to the order Holectypoida or the order Cassiduloida is still a matter of debate. Wagner \& Durham (1966) placed this genus, together with Amblypygus and Rhopostoma, in the order Holectypoida (suborder uncertain), since these taxa lacked the cassiduloid floscelle and showed some resemblance to representatives of the suborder Echinoneina, i.e. gross morphology and lack of lantern, but ambulacra subpetaloid. Ernst (1973) considered placement with the Cassiduloida improbable, on account of the absence of a floscelle. Rose (1982), who reviewed the post-1966 (Wagner \& Durham, 1966) taxonomic history of the Holectypoida, ascribed Amblypygus to the family Echinoneidae (Holectypoida) and Rhopostoma to the Cassiduloida (family Nucleolitidae), but did not change the position of Echinogalerus (suborder uncertain). According to Schulz (1985), Echinogalerus might belong to the Cassiduloida. Smith et al. (1988) placed the genus in the family Galeritidae (Holectypoida, suborder Echinoneina), while Smith \& Wright (1999) excluded the suborder Echinoneina from the Holectypoida, raising it to the rank of order (Echinoneoida) as sister group to the Cassiduloida (and Clypeasteroida). The genus Echinogalerus was subdivided, with the subgenus Rostrogalerus Lambert, 1911 being placed, as a genus, in the Echinoneoida (family Galeritidae). The other species, including the type E. faba, were referred to the Cassiduloida (see also Smith et al., 1999). Rostrogalerus was differentiated by Lambert (1911) and Smith \& Wright (1999) by its more rostrate posterior, circular peristome and nonpetaloid ambulacra (adapical pore pairs not enlarged). Smith \& Wright (1999) considered it to be very close to Galerites, differing only in its small size and higher position of the periproct.

The borderline between Echinogalerus and Galerites has always been somewhat vague. Schulz (1985) treated a number of species of Galerites, viz. G. hannoniensis, G. hemisphaericus and $G$. sulcatoradiatus, as well as a few undescribed related taxa, all differing from the other Galerites species in their relatively wide ambulacra around the peristome, as possibly belonging to Echinogalerus. Also, Galerites was suspected to be a cassiduloid by that author. The species of $G a$ lerites which were provisionally transferred to Echinogalerus differ from true Galerites in having circular tests, nonpetaloid ambulacra and, in part, more circular peristomes. However, Smith \& Wright (1999) maintain these species in Galerites; in their view Echinogalerus should be restricted to species with a subtriangular (oblique) peristome and subpetaloid ambulacra, while Galerites should contain species with a circular peristome and nonpetaloid ambulacra.

We consider it difficult to evaluate the ordinal position of Echinogalerus so long as many species are still insufficiently known. Moreover, Schulz (1985) mentioned the existence of two undescribed, possibly related, genera from the Maastrichtian of northern Germany and Denmark that would be intermediate 

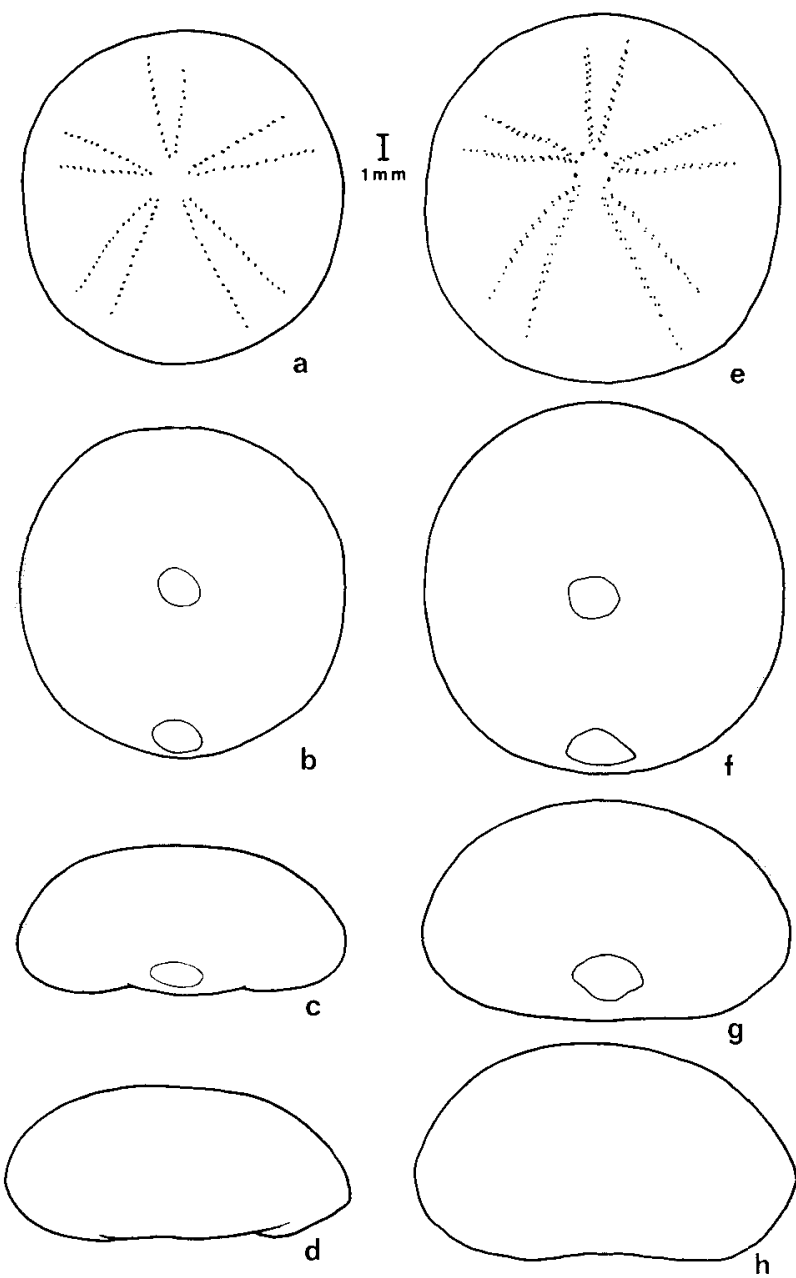

E. vetschauensis

Fig. 9. Camera-lucida illustrations of $E$. vetschauensis (a-d: length $13.5 \mathrm{~mm}$, Van Birgelen Colln, no. 1378, Lixhe Chalk, Wahlwiller Bed, Nijswiller; e-h: length $15.0 \mathrm{~mm}$, Van Birgelen Colln, no. 716, Kunrade Chalk, highway Benzenrade). a, e: upper surface; $b$, f: lower surface; $c$, g: posterior; $d$, h: left side.

between Galerites and certain cassiduloids. In addition to the poorly known species of Echinogalerus, these two genera should be duely considered in a discussion on the subdivision and ordinal position(s) of Echinogalerus. Below, our current views on the relationship of Echinogalerus species from the Maastrichtian type area and species from elsewhere are presented. This brief overview may stimulate discussions on the ordinal and infrageneric classification of the genus.

\section{Infrageneric relationship of Echinogalerus}

Within the genus Echinogalerus, the five species from the Maastrichtian type area make up a diverse group. However, when some relatively well-known species from other areas are taken into account, this allows to distinguish several groups of more closely related species. One such group includes the following species, all of which clearly have double pores aborally (ambulacra subpetaloid), an oblique peristome and a relatively large, triangular periproct:

E. faba (Desor, 1842) (Cenomanian of southwest England and western France);

E. goslariensis (Schlüter, 1902) (Santonian of northern Germany);

E. muelleri (Schlüter, 1902) (Maastrichtian of northern Spain and SE Netherlands).

E. rutoti (Lambert, 1898) (Maastrichtian of southern Belgium);

A second group comprises species with small pore pairs, sunken in small pits aborally, and non-petaloid ambulacra, an oblique peristome and a relatively large, triangular periproct:

E. bueltenensis (Schlüter, 1902) (Santonian of northern Germany);

E. peltiformis (Wahlenberg, 1821) (Campanian of southern Sweden and northern Germany).

A third group consists of species with a circular ambitus, small pore pairs sunken in small pits, nonpetaloid ambulacra, a circular peristome and a small, vaguely triangular to circular periproct:

E. circularis (Schlüter, 1902) (Turonian of western Germany);

E. tenuiporus (Schlüter, 1902) (Maastrichtian of northern Germany);

E. vetschauensis (Schlüter, 1902) (Maastrichtian of northern Spain and SE Netherlands).

Echinogalerus dolfussi (Lambert, 1898) and E. trunca-

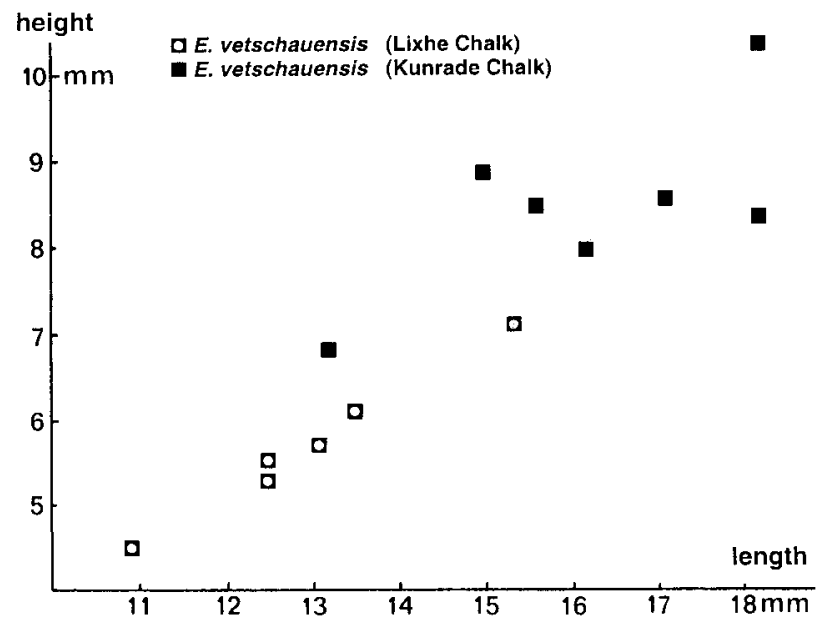

Fig. 10. Graph showing height/length values of 13 well-preserved specimens of $E$. vetschauensis (Lixhe Chalk, Wahlwiller Bed, Nijswiller, $\mathrm{n}=6$; Kunrade Chalk, highway Benzenrade, $\mathrm{n}=7$ ). 

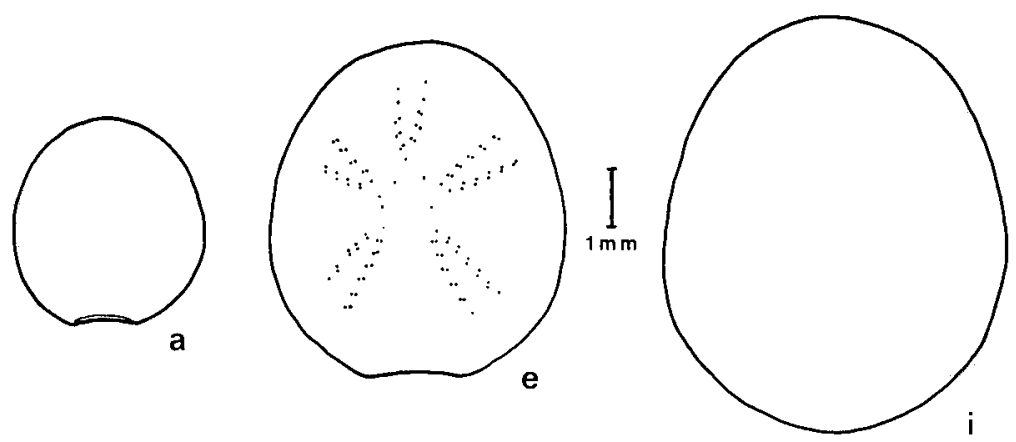

Fig. 11. Camera-lucida illustrations of $E$. minutus (a-d: length $3.7 \mathrm{~mm}$, NHMM JJ 9521, 4e-1: length 5.9, 7.4 mm, Van Birgelen Colln, no. 784, Meerssen Chalk, IVf4, Blom quarry, Berg). a, e, i: upper surface; $b, f, j$ : lower surface; $c, g$, k: posterior; $d, h, 1$ : left side.
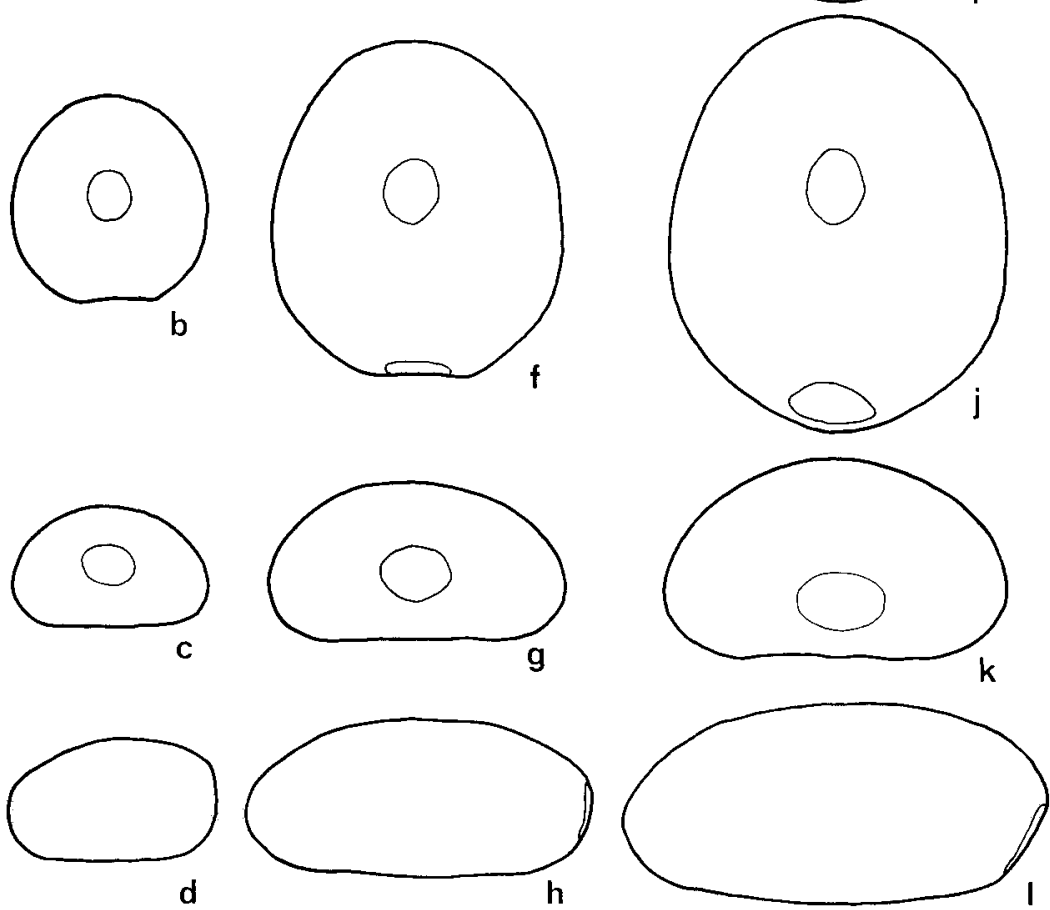

E. minutus

tus (d'Orbigny, 1857), both from the Maastrichtian of western France (the latter possibly also occurring in the Campanian of western Germany; see Schlüter, 1902), might also belong to this group.

It is difficult to ally other species of Echinogalerus to the species groups listed above. Echinogalerus belgicus and $E$. pusillus, both from the Maastrichtian of SE Netherlands, have simple pores, but in all other respects they are clearly different (see above). Echinogalerus minutus, from the Maastrichtian of SE Netherlands, resembles E. gehrdensis (Roemer, 1841) from the Santonian of northern Germany. Both have clearly double pores aborally and a symmetrical peristome. However, the latter differs by its more anterior apex, clearly rostrate posterior and more inframarginal periproct. The clearly inframarginal periproct separates E. gehrdensis also from the rostrate E. rostratus (Desor, 1842) from the Cenomanian of southwest England and western France.

The following species are poorly known: E. (Rostro- galerus) orbicularis (Desor, 1842) from the Cenomanian of western France, E. (R.) althi (Zareczny, 1878) from the Turonian(?) of Poland, and E. laubei (Novák, 1887) from the Turonian of Bohemia (Czech Republic). Echinogalerus bochotnicensis Kongiel, 1950, from the Maastrichtian of Poland, is not an Echinogalerus, but closely resembles Hemicara pomeranum Schlüter, 1902, whereas E. avellana (Dubois, 1840) and E. globosus (Roemer, 1841) belong to Galerites (see Lambert \& Thiéry, 1925 and Schulz, 1985, respectively).

\section{Acknowledgements}

We thank J. Bergström and I. Chef Holmberg (Swedish Museum of Natural History, Stockholm), M.C. Halter (Aachen), J.W.M. Jagt and H. Peeters (Natuurhistorisch Museum Maastricht), F.J. Krüger (Braunschweig), M. Kutscher (Sassnitz), M.M.M. Kuypers (Ittervoort), H. van Loo (Simpelveld), C. Neumann (Museum für Naturkunde, Humboldt Universität Berlin), J. Nillesen (Eys), H.-V. Thiel 
(Düsseldorf), C. Vlieks-Rademakers (Simpelveld), L. Walschot (Riemst) and G. Zuidema (Driehuis) for making material available, and W.M. Felder (Vijlen), J.W.M. Jagt, C. Neumann and A.B. Smith (Natural History Museum, London) for information and review of an earlier typescript. J.W.M. Jagt and J. Reynders (Houthalen) provided the photographs of $E$. minutus, E. muelleri and E. pusillus. This is contribution No. 15 of the 'Vijlen Werkgroep'.

\section{References}

Binkhorst van den Binkhorst, J.-T., 1859. Esquisse géologique et paléontologique des couches crétacées du Limbourg. Van OschAmerica et Cie (Maastricht): 268 pp.

Bosquet, J., 1860. Versteeningen uit het Limburgsche Krijt. In: W.C.H. Staring. De Bodem van Nederland, 2. A.C. Kruseman (Haarlem): 361-418.

Bosquet, J., 1868. Fossiles du massif crétacé du Limbourg. In: G. Dewalque. Prodrome d'une description géologique de la Belgique. J.-G. Carmanne (Liège): 355-387.

Bosquet, J., 1879. Liste des fossiles du massif crétacé du Limbourg. In: C. Ubaghs. Description géologique et paléontologique du sol du Limbourg. J.J. Romen \& Fils (Roermond): 197-237.

Cotteau, G., 1875. Note sur les Échinides crétacés de la province de Hainaut. Bulletin de la Société géologique de France (3)2: 638-660.

Desor, E., 1842. Des Galérites. Monographies d'Échinodermes vivans et fossiles, 3. Petitpierre (Neuchâtel): $94 \mathrm{pp}$.

Dubois, F., 1840. Voyage autour du Caucase, chez les Tserkesses et

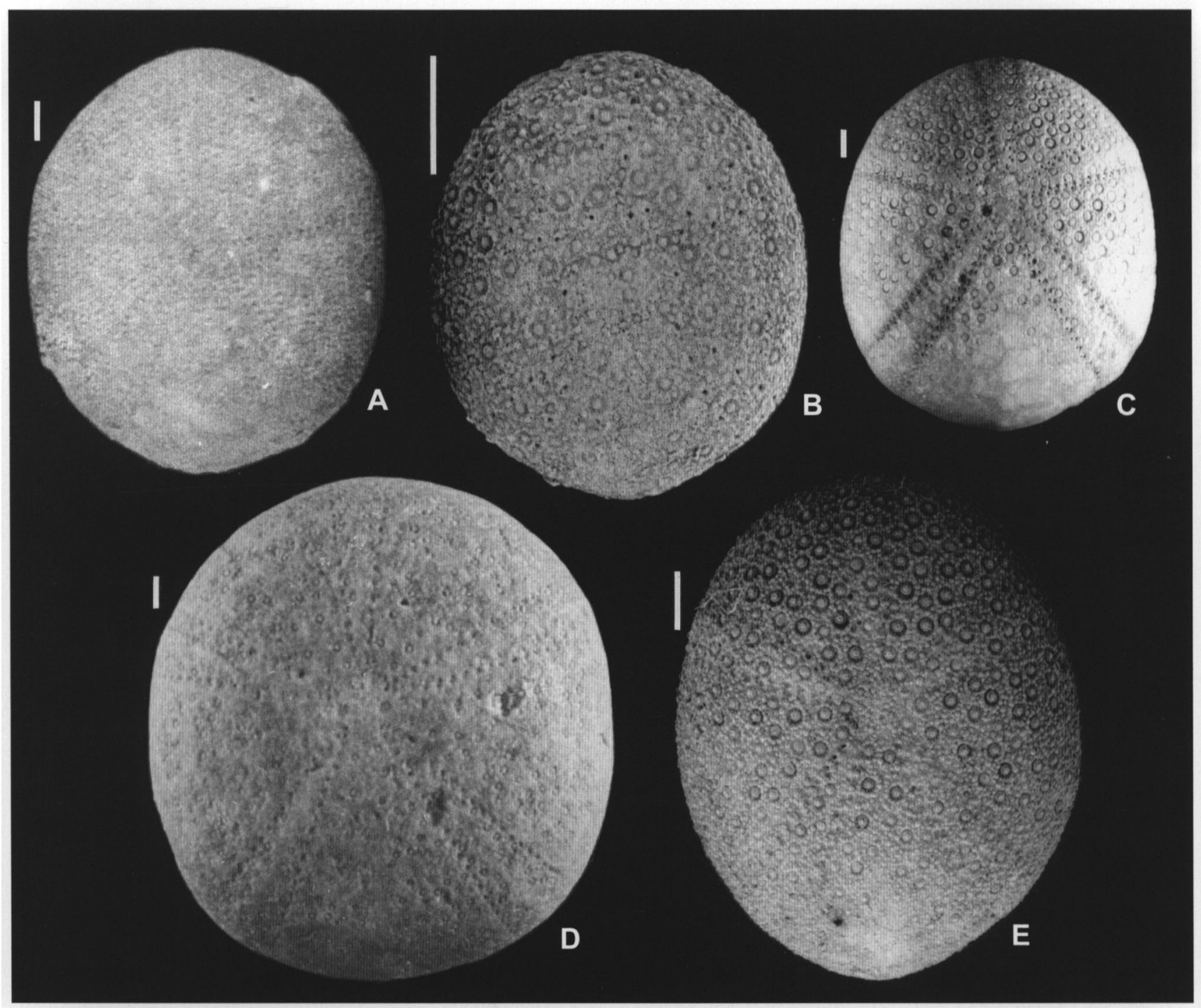

Fig. 12. Photo (a, c, d) and scanning (b, e) electron micrographs of upper surfaces, showing aboral ambulacral pores and details of tuberculation (scale bar $=1 \mathrm{~mm}$ ). a: E. belgicus, length $10.7 \mathrm{~mm}$, Van Birgelen Colln, no. 477, Lixhe Chalk, Wahlwiller Bed, Schneeberg; b: E. pusillus, length $3.7 \mathrm{~mm}$, Halter Colln, unnumbered, Vijlen Chalk, Aachen; c: E. muelleri, length $12.8 \mathrm{~mm}$, NHMM BL 0822, Kunrade Chalk, Kunrade area; d: E. vetschauensis, length $16.2 \mathrm{~mm}$, Vlieks Colln, unnumbered, Kunrade Chalk, highway Benzenrade; e: E. minutus, length $8.8 \mathrm{~mm}$, NHMM K 750, Meerssen Chalk, IVf4, Blom quarry, Berg. 
les Abkhuse, en Colchide, en Géorgi, en Arménie et en Crimée, 4. Paris.

Ernst, G., 1973. Die Echiniden-Fauna des Santon der Gehrdener Berge. Berichte der naturhistorischen Gesellschaft zu Hannover 117: 79-102.

Felder, W.M., 1980. Krijt. In: O.S. Kuyl (ed): Toelichtingen bij de geologische kaart van Nederland 1:50.000, blad Heerlen. Rijks Geologische Dienst (Haarlem): 31-53.

Gallemí, J., 1977. Los yacimientos con equínidos del nivel 'Homes Morts' entre los ríos N. Pallaresa y N. Ribagorzana (Cret. Sup. del Prepirineo de Lérida). Publicaciones geologicas de Universitat Autònoma de Barcelona 6: $92 \mathrm{pp}$.

Grossouvre, A. de, 1895-1901. Recherches sur la craie supérieure. Mémoires pour servir à l'explication de la carte géologique détaillée de la France. Imprimerie Nationale (Paris): 1013 pp.

Jagt, J.W.M., 2000. Late Cretaceous-Early Palaeogene echinoderms and the $\mathrm{K} / \mathrm{T}$ boundary in the southeast Netherlands and northeast Belgium - Part 4: Echinoids. Scripta Geologica 121: 181-375.

Jagt, J.W.M., Deckers, M., Dhondt, A.V., Dortangs, R.W., Felder, P.J., Felder, W.M., Jäger, M., Keutgen, N., Kuypers, M., Michels, G., Reynders, J., Simon, E., van der Ham, R., van Knippenberg, P. \& van Neer, R., 1995. Preliminary report of field work at Altembroeck (NE Belgium, early Maastrichtian) by the Working Group Beutenaken/Vijlen Members. Service géologique de Belgique, Professional Paper 1995/1 (276): 1-20.

Kongiel, R., 1950. O kilku nowych jeżowcach z górnego mastrychtu okolic Pulaw. Acta geologica polonica 1: 311-329.

König, C., 1825. Icones fossilium sectiles, 1. London: $4 \mathrm{pp}$.

Kutscher, M., 1979. Neue Echiniden aus dem Unter-Maastricht der Insel Rügen. 3. Vertreter der Gattungen Echinogalerus König, 1825 und Galerites Lamarck, 1801. Zeitschrift für geologische Wissenschaften 7: 559-569.

Lambert, J., 1898. Note sur les échinides de la Craie de Ciply. Bulletin de la Société belge de Géologie, de Paléontologie et d'Hydrologie 11: 141-189.

Lambert, J., 1911. Description des échinides crétacés de la Belgique, 2. Mémoires du Musée royal d'Histoire naturelle de Belgique 16: 1-81.

Lambert, J., 1927. Révision des échinides fossiles de la Catalogne. Memorias del Museo de Ciencias naturales de Barcelona (Geológia) 1: 1-102.

Lambert, J. \& Thiéry, P., 1909-1925. Essai de nomenclature raisonnée des échinides. Librairie Ferrière (Chaumont): $607 \mathrm{pp}$.

Leske, N.G., 1778. Jacobi Theodori Klein naturalis dispositio Echinodermatum. Addidamenta ad I.T. Klein naturalem dispositionem Echinodermatum. Leipzig (G.E. Beer): 175 pp.

Meijer, M., 1956. Notes sur les échinides du Tuffeau de Maastricht (Maastrichtien, Dumont, 1849), 1. Echinogalerus (Rostrogalerus) transversus (Smiser). Natuurhistorisch Maandblad 45: 38-44.

Meijer, M., 1965. The stratigraphical distribution of Echinoids in the Chalk and Tuffaceous Chalk in the neighbourhood of Maastricht (Netherlands). Mededelingen van de Geologische Stichting 17: 21-25.

Müller, J., 1846. Beiträge zur Petrefacten-Kunde der Aachener Kreide. Jahresbericht über den Schulcursus 1845-46 am Königlichen Gymnasium zu Aachen 1846: 1-20.

Neumann, C., Jagt, J.W.M. \& Van der Ham, R.W.J.M., 2002. Rare Campanian echinoids from Höver and Misburg (Hannover area, Lower Saxony, Germany). Mitt. Mus. Naturkde Berlin, geowiss. Reihe 5: 121-139.

Novák, O., 1887. Studien an Echinodermen des böhmischen Kreideformation, 1. Die irregulären Echiniden der Cenomanstufe. Abhandlungen der königlichen böhmischen Gesellschaft für Wissenschaften 6:47 pp.
Orbigny, A. d', 1854-1860. Paléontologie française. Terrains crétacés, 6. Échinodermes. Victor Masson (Paris): $596 \mathrm{pp}$.

Roemer, F.A., 1840-1841. Die Versteinerungen des norddeutschen Kreidegebirges. Hahn'sche Hofbuchhandlung (Hannover): iv + $145 \mathrm{pp}$.

Rose, E.P.F., 1982. Holectypoid echinoids and their classification. In: J.M. Lawrence (Ed.): Echinoderms, Proceedings of the International Conference, Tampa Bay. A.A. Balkema (Rotterdam): 145-152.

Schlüter, C., 1892. Die regulären Echiniden der norddeutschen Kreide, 2. Cidaridae, Salenidae. Abhandlungen der königlich preussischen geologischen Landesanstalt, n.s. 5: 145-315.

Schlüter, C., 1902. Zur Gattung Caratomus. Zeitschrift der deutschen geologischen Gesellschaft 54: 302-335.

Schulz, M.-G., 1985. Die Evolution der Echiniden-Gattung Galerites im Campan und Maastricht Norddeutschlands. Geologisches Jahrbuch A80: 3-93.

Smiser, J.S., 1935. A monograph of the Belgian Cretaceous echinoids. Mémoires du Musée royal d'Histoire naturelle de Belgique 68: 1-98.

Smith, A.B., Gallemí, J., Jeffery, C.H., Ernst, G. \& Ward, P.D., 1999. Late Cretaceous-early Tertiary echinoids from northern Spain: implications for the Cretaceous-Tertiary extinction event. Bulletin of the Natural History Museum London (Geology) 55 : 81-137.

Smith, A.B. \& Jeffery, C.H., 2000. Maastrichtian and Palaeocene echinoids: a key to world faunas. Special Papers in Palaeontology 63: 1-406.

Smith, A.B., Paul, C.R.C., Gale, A.S. \& Donovan, S.K., 1988. Cenomanian and Lower Turonian echinoderms from Wilmington, south-east Devon, England. Bulletin of the British Museum of Natural History (Geology) 42: 1-245.

Smith, A.B. \& Wright, C.W., 1999. British Cretaceous echinoids. Part 5, Holectypoida, Echinoneoida. Monograph of the Palaeontographical Society London 153(612): 343-390.

Van Birgelen, M. \& Van der Ham, R., 1999. Echinogalerus-soorten uit het Gulpens Krijt (Maastrichtien) van Zuid-Limburg, de Voerstreek en de Schneeberg. Natuurhistorisch Maandblad 88: 215-218.

Van Birgelen, M. \& Van der Ham, R., 2000. Nòg een Echinogalerus-soort uit het Gulpens Krijt. Natuurhistorisch Maandblad 89: 266-268.

Van der Ham, R., De Wit, W., Zuidema, G. \& Van Birgelen, M., 1987. Zeeëgels uit het Krijt en Tertiair van Maastricht, Luik en Aken: een atlas van de zeeëgels uit het Campaniën, Maastrichtiën en Daniën van Zuid-Limburg en aangrenzende delen van België en Duitsland. Publicaties van het Natuurhistorisch Genootschap in Limburg 36: 1-91.

Van der Ham, R. \& Van Birgelen, M., 1992 Zeeëgels uit het Maastrichtien van de Schneeberg en omgeving (Aken, Duitsland). Natuurhistorisch Maandblad 81: 139-153.

Van der Ham, R. \& Van Birgelen, M., 2000 Echinogalerus-soorten uit het Kunrader en Maastrichts Krijt (Maastrichtien) van ZuidLimburg, het Albertkanaal en Vetschau. Natuurhistorisch Maandblad 89: 35-39.

Wahlenberg, G., 1821. Petrificata telluris Svecanae. Nova Acta regiae Societatis scientiarum Upsaliensis 8: 1-116.

Wagner, C.D. \& Durham, J.W., 1966. Holectypoida. In: Moore, R.C. (Ed.): Treatise on invertebrate paleontology, part U3(2). University of Kansas Press (Lawrence) and Geological Society of America, Boulder: U440-U450.

Zareczny, S., 1878. O rednich warstwach kredewych w krakowskin okr-gu. Sprawozdanie Komision fisyograficezke Towarszytwa Nauk Kraków 12: 176-254 (not seen). 